\title{
Characterization of Leachate from Kuala Sepetang and Kulim Landfills: A Comparative Study
}

\author{
Noor Ainee Zainol ${ }^{1}$, Hamidi Abdul Aziz ${ }^{1} \&$ Mohd Suffian Yusoff $^{1}$ \\ ${ }^{1}$ School of Civil Engineering, Universiti Sains Malaysia, 14300 Nibong Tebal, Penang, Malaysia \\ Correspondence: Hamidi Abdul Aziz, School of Civil Engineering, Universiti Sains Malaysia, 14300 Nibong \\ Tebal, Penang, Malaysia. Tel: 60-4599-5999 ext.6201/6204. E-mail: cehamidi@eng.usm.my
}

Received: June 11, 2012 Accepted: June 25, 2012 Online Published: August 15, 2012

doi:10.5539/eer.v2n2p45 URL: http://dx.doi.org/10.5539/eer.v2n2p45

\begin{abstract}
The general characteristics of Kuala Sepetang Landfill Site (KSLS) and Kulim Landfill Site (KLS) in the northern part of Malaysia were investigated. The average values of the parameters for leachate at KSLS and KLS, such as $\mathrm{pH}(8.05$ and 7.59), EC (11.9 and $2.92 \mathrm{mS} / \mathrm{cm})$, ORP (-33.02 and $+17.8 \mathrm{mV})$, turbidity (88.9 and 26 NTU), colour (2200 and $326 \mathrm{Pt} \mathrm{Co})$, SS (233 and $47 \mathrm{mg} / \mathrm{L}), \mathrm{BOD}_{5}(158$ and $29 \mathrm{mg} / \mathrm{L}), \mathrm{COD}(855 \mathrm{and} 117 \mathrm{mg} / \mathrm{L})$, $\mathrm{BOD}_{5} / \mathrm{COD}(0.19$ and 0.24$)$, ammonia-N (857 and $\left.210 \mathrm{mg} / \mathrm{L}\right)$, sulphate $(91.48$ and $141.71 \mathrm{mg} / \mathrm{L}), \mathrm{chloride}$ $(1800.46$ and $243.18 \mathrm{mg} / \mathrm{L})$, copper $(0.08$ and $0.03 \mathrm{mg} / \mathrm{L})$, iron $(2.18$ and $0.38 \mathrm{mg} / \mathrm{L})$, manganese $(0.08$ and 0.09 $\mathrm{mg} / \mathrm{L})$, nickel $(0.16$ and $0,07 \mathrm{mg} / \mathrm{L})$, and zinc $(0.26$ and 0.09$)$, were recorded, respectively. Results of this study indicate that KSLS and KLS had low refractory $\left(\mathrm{BOD}_{5} / \mathrm{COD}\right)$ organic compounds and high quantities of COD and ammonia-N. Furthermore, the amounts of colour, suspended solid (SS), BOD 5, COD, ammonia-N, and sulphate exceeded the standard limits imposed by the Environmental Quality (Control of Pollution from Solid Waste Transfer Station and Landfill) Regulations 2009, Malaysian Environmental Quality Act 1974 (Act 127). On the other hand, parameters such as $\mathrm{pH}$, copper, iron, manganese, nickel, and zinc remained within the allowable limits. The measured leachate would need an appropriate treatment strategy to reduce the pollutants to a satisfactory level prior to discharge into receiving system.
\end{abstract}

Keywords: solid waste, sanitary landfill, leachate

\section{Introduction}

Rapid industrialization, increase in population and changes in consumption pattern directly and indirectly result in the generation of a large amount of municipal and industrial wastes, ranging from biodegradable to synthetic. In Malaysia, solid waste management has become a major environmental problem. Over 23,000 tonnes of waste is produced daily in Malaysia. By 2020, the amount is expected to have risen to 30,000 tonnes. The amount of waste generated continues to increase due to the rising population and developmentof the country. Less than $5 \%$ of the waste is being recycled.

Sanitary landfilling has been the most popular methods of solid waste disposal in many countries, including Malaysia. There are more than 296 landfills throughout Malaysia. Most of the landfills are open dumping grounds, and they pose serious environmental and social threats (Manaf et al., 2009). Landfills have been accepted as the most economical and environment friendly way for the disposal of solid waste compared with other disposal methods, such as composting, incineration, and gasification. However, a major concern associated to this disposal method is the leachate produced from the landfills.

The production of leachate is principally caused by percolation of precipitation through waste deposited in a landfill. Landfill leachate mainly consists of large amounts of organic matter including dissolved organic matter, phenol, ammonical-nitrogen, phosphate, heavy metals, sulphide, hardness, acidity, alkalinity, salinity, solids, inorganic salts, and other toxicant (Foul et al., 2009; Aziz et al., 2009; Renou et al., 2008; Kang et al., 2002; Wang et al., 2002). The complexity of these characteristics makes the leachate more difficult to manage. Therefore, the treatment of landfill leachate constituents prior to its discharge is a legal necessity to avoid pollution of water bodies and to prevent both severe and continual toxicity (Öman \& Junestedt, 2008; Sanphoti et al., 2006; Tatsi et al., 2003). 
The quality of leachate produced are variable in both volumetric flow and chemical composition (Renou et al., 2008). The variation of leachate compositions depends on various factors, including waste composition, age of landfill, site hydrogeology, specific climate conditions, moisture routing through the landfill, and the landfill design and operation (Ghafari et al., 2010; Aziz et al., 2004).

Leachate from a young landfill (less than five years) is typically characterized by high $\mathrm{BOD}_{5}$ and $\mathrm{COD}$ concentrations, quite high amount of $\mathrm{NH}_{3}-\mathrm{N}$, high ratio of $\mathrm{BOD}_{5} / \mathrm{COD}$, and $\mathrm{pH}$ value below 6.5. In contrast, leachate from a mature or stabilized landfill (over 10 years) usually highly contaminated with $\mathrm{NH}_{3}-\mathrm{N}$, moderately high strength of $\mathrm{COD}$, and $\mathrm{BOD}_{5} / \mathrm{COD}$ ratio lower than 0.1. Biological treatment processes are effective for young leachate, but are ineffective for leachate from stabilized leachate. In general, physical-chemical methods which are not favoured for young leachate treatment are advised for mature or stabilized leachate (Rivas et al., 2004; Amokrane et al., 1997).

The main purpose of this research is to study the characteristics of leachate in two anaerobic sanitary landfills, namely, Kuala Sepetang Landfill Site (KSLS) and Kulim Landfill Site (KLS), both of which are located in the northern part of Peninsular Malaysia. The results obtained were compared with the data published by previous researchers and the Malaysia Environmental Quality Act 1974 (MDC, 2010). This study aims to serve as a reference for the implementation of the most suitable technique for reducing the negative environmental effects of discharged leachate.

\section{Materials and Methods}

\subsection{Leachate Sampling}

The leachate samples were collected from KSLS and KLS. The samples were collected at two week intervals, within about three months from January to March 2012. The collection and preservation of samples were done in accordance with the Standard Methods for the Examination of Water and Wastewater (APHA, 2005). The collected samples were stored in a room with a temperature of $4{ }^{\circ} \mathrm{C}$ prior to use for experimental purposes to minimize biological and chemical reactions.

\subsection{Site Characteristics}

\subsubsection{Kuala Sepetang Landfill Site (KSLS)}

KSLS is situated at $40^{\circ} 49^{\prime} 20.08^{\prime \prime} \mathrm{N}$ and $100^{\circ} 40^{\prime} 44.08^{\prime \prime} \mathrm{E}$ near the town of Taiping, Perak, Malaysia. It encompasses a total area of 12 ha and is equipped with a leachate collection pond. The landfill receives about 300 tons of solid waste daily and is classified as an improved anaerobic landfill. The landfill is more than 14 years old. Some recycling is practiced at the site, mainly by scavengers, and the remaining waste is dumped in individual phases. The leachate is collected in a collection pond, which acts as a retention pond. However, no further treatment is provided before the leachate is discharged.

\subsubsection{Kulim Landfill Site (KLS)}

KLS is located $12 \mathrm{~km}$ from the town of Kulim, Kedah, Malaysia. It is surrounded by a palm oil plantation. The total area of the landfill is 56 ha and its depth is about $20 \mathrm{~m}$. The landfill receives about 240 tons of municipal solid wastes daily. It is an open dumping site that started operations in 1996. This landfill is equipped with a leachate collection system. The leachate produced is conveyed by a corrugated HDPE pipe with diameter of 30 $\mathrm{cm}$ to a lined collection pond. It is then discharged to the natural environment without any treatment.

\subsection{Characterization of Leachate}

The samples were characterized in terms of $\mathrm{pH}$, electrical conductivity (EC), oxidation-reduction potential (ORP), turbidity, colour, suspended solids $(\mathrm{SS}), \mathrm{BOD}_{5}, \mathrm{COD}, \mathrm{BOD}_{5} / \mathrm{COD}$, ammonia-N, sulphate, chloride, iron $(\mathrm{Fe})$, copper $(\mathrm{Cu})$, nickel $(\mathrm{Ni})$, manganese $(\mathrm{Mn})$, and zinc $(\mathrm{Zn})$. Measurement of the parameters was conducted in triplicate according to the Standard Method of Water and Wastewater (APHA, 2005). The values of the parameters obtained were compared with the data published by previous researchers and the Environmental Quality Act of Malaysia 1974 (MDC, 2010).

\section{Results and Discussions}

Table 1 shows the characteristics of leachate at KSLS and KLS, and the range and average values for the measured parameters 
Table 1. Characteristics of raw leachate at KSLS (six samples) and KLS (four samples) from January 2012 to March 2012

\begin{tabular}{|c|c|c|c|c|c|c|}
\hline \multirow{2}{*}{ No. } & \multirow{2}{*}{ Parameter } & \multicolumn{2}{|c|}{ KSLS } & \multicolumn{2}{|c|}{ KLS } & \multirow{2}{*}{$\frac{\text { Standard }}{\text { Discharge }^{\mathrm{a}} \text { limi }}$} \\
\hline & & Range & Average & Range & Average & \\
\hline 1 & $\mathrm{pH}$ & $7.86-8.31$ & 8.05 & $7.27-7.92$ & 7.59 & $6.0-9.0$ \\
\hline 2 & $\mathrm{EC}(\mathrm{mS} / \mathrm{cm})$ & $5.71-22.52$ & 11.90 & $2.57-3.54$ & 2.92 & - \\
\hline 3 & ORP $(\mathrm{mV})$ & $-84.9-+91.4$ & -33.02 & $-33.3-+116.4$ & +17.8 & - \\
\hline 4 & Turbidity (NTU) & $40.3-178$ & 88.9 & $12.7-67$ & 26 & - \\
\hline 5 & Colour (Pt Co) & $1120-3100$ & 2220 & $192-440$ & 326 & 100 \\
\hline 6 & $\mathrm{SS}(\mathrm{mg} / \mathrm{L})$ & $151-278$ & 233 & $11-99$ & 47 & 50 \\
\hline 7 & $\mathrm{BOD}_{5}(\mathrm{mg} / \mathrm{L})$ & $97-184$ & 158 & $7-69$ & 29 & 20 \\
\hline 8 & $\mathrm{COD}(\mathrm{mg} / \mathrm{L})$ & $680-950$ & 855 & $105-131$ & 117 & 400 \\
\hline 9 & $\mathrm{BOD}_{5} / \mathrm{COD}$ & $0.11-0.26$ & 0.19 & $0.06-0.52$ & 0.24 & - \\
\hline 10 & Ammonia-N(mg/L) & $410-1185$ & 857 & $174-280$ & 210 & 5 \\
\hline 11 & Sulphate $(\mathrm{mg} / \mathrm{L})$ & $22.47-175.07$ & 91.48 & $65.83-217.59$ & 141.71 & 0.5 \\
\hline 12 & Chloride (mg/L) & $837.60-3025.21$ & 1800.46 & $194-292.35$ & 243.18 & - \\
\hline 13 & Copper (mg/L) & $0.002-0.15$ & 0.08 & $0.02-0.07$ & 0.03 & 0.20 \\
\hline 14 & $\operatorname{Iron}(\mathrm{mg} / \mathrm{L})$ & $0.96-3.65$ & 2.18 & $0.24-0.71$ & 0.38 & 5.0 \\
\hline 15 & Manganese $(\mathrm{mg} / \mathrm{L})$ & $0-0.21$ & 0.08 & $0-0.14$ & 0.09 & 0.20 \\
\hline 16 & Nickel (mg/L) & $0.09-0.23$ & 0.16 & 0.06-0.09 & 0.07 & 0.20 \\
\hline 17 & Zinc (mg/L Zn) & $0.14-0.34$ & 0.26 & $0.01-0.29$ & 0.09 & 2.0 \\
\hline
\end{tabular}

\subsection{General Characteristics}

\section{$3.1 .1 \mathrm{pH}$}

The $\mathrm{pH}$ values varied at 7.86-8.31 and 7.27-7.92 for KSLS and KLS, respectively. The results are consisten with those published by previous authors (Aziz et al., 2010; Palaniandy et al., 2010; Zhong et al., 2009). Higher pH values of 8.3-9.10 were recorded from the stabilized leachate of semi-aerobic landfill (Bashir et al., 2010). However, a lower range of $\mathrm{pH}$ values between 6.8-7.5 was previously reported (Jokela et al., 2002). The $\mathrm{pH}$ varied according to the age of landfills (Kulikowska et al., 2008). Generally, the $\mathrm{pH}$ of a stabilized leachate is higher than that of a young leachate. The difference could be due to the stabilized leachate that is produced after or during the fermentation of methane; hence the $\mathrm{pH}$ is higher than 7.5 (Poznyak et al., 2003). The $\mathrm{pH}$ values remained within the permissible limit (6.0-9.0) set in the Environmental Quality (Control of Pollution from Solid Waste Transfer Station and Landfill) Regulations 2009, Malaysian Environmental Quality Act 1974 (Act 127) (Aziz et al., 2010; Aghamohammadi et al., 2007; Aziz et al., 2007).

\subsubsection{Electrical Conductivity}

The maximum values of EC for leachate at KSLS and KLS were 22.52 and $3.54 \mathrm{mS} / \mathrm{cm}$, respectively, while the minimum values were 5.71 and $2.57 \mathrm{mS} / \mathrm{cm}$, respectively. The results obtained are consistent with the values obtained in previous studies (Aziz et al., 2010; Bashir et al., 2010; Tatsi \& Zouboulis, 2002), which were $5.25-13.92,22.25-25.06$, and $3.2-82.1 \mathrm{mS} / \mathrm{cm}$, respectively.

\subsubsection{Oxidation-reduction Potential}

The maximum values of ORP for leachate at KSLS and KLS were +91.4 and $+116.4 \mathrm{mV}$, respectively, while the minimum values were -84.9 and $-33.3 \mathrm{mV}$, respectively. The ORP values in this study are consistent with previously published data (Tatsi \& Zouboulis, 2002). The increase in ORP readings from negative to positive values at both sites reflects the degree of leachate stabilization (Tatsi \& Zouboulis, 2002).

\subsubsection{Turbidity}

Turbidity of leachate ranged from 40.3-178 and from 12.7-67 NTU for KSLS and KLS, respectively. The leachate at KSLS contained higher turbidity than that at KLS due to the landfill age and stabilization of leachate. 
The turbidity values in the present study are consistent with those in previous studies (Aziz et al., 2009; Aziz et al., 2004; Tatsi et al., 2003).

\subsubsection{Colour}

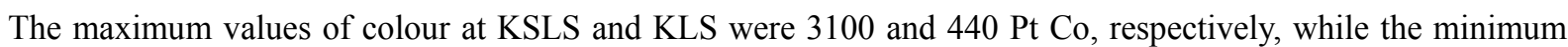
values were 1120 and $192 \mathrm{Pt} \mathrm{Co,} \mathrm{respectively.} \mathrm{The} \mathrm{leachate} \mathrm{at} \mathrm{KSLS} \mathrm{contained} \mathrm{higher} \mathrm{concentration} \mathrm{of} \mathrm{colour}$ compared with that at KLS. For KSLS, colour concentration ranged from 1120-3100 Pt Co, which were similar to previously published values (Tatsi et al., 2003). However, wider ranges of 5330-5760, 2430-8189, and 3790-4010 Pt Co were obtained by other studies (Bashir et al., 2010; Aziz et al., 2007; Mohajeri et al., 2010). The high concentration of colour in landfill leachate is due to the presence of high organic substances (Aziz et al., 2007).

\subsubsection{Suspended Solid}

The average values of SS at KSLS and KLS were 233 and $47 \mathrm{mg} / \mathrm{L}$, respectively. Smaller values of 38-96, 132, $78-80 \mathrm{mg} / \mathrm{L}$ were obtained in previous studies (Ghafari et al., 2010; Mohajeri et al., 2010; Aghamohammadi et al., 2007), confirming results of this study. Greater SS values of 1431 and $707 \mathrm{mg} / \mathrm{L}$ were obtained at semi-aerobic Pulau Burung Landfill Site (PBLS) and anaerobic Kulim landfill Site (Aziz et al., 2010). Typical SS values of 200-2000 and 100-400 mg/L were recorded for the new (less than two years) and mature landfills (more than 10 years), respectively (Tchobanoglous et al., 1993). The SS value for KSLS in this study was greater than the permissible Malaysian standard level $(50 \mathrm{mg} / \mathrm{L})$, while the SS value for KSL was still within the allowed limit.

\subsection{7 $\mathrm{BOD}_{5}$}

In this study, the $\mathrm{BOD}_{5}$ values for leachate at KSLS and KLS varied at 97-184 and 7-69 mg/L, respectively. $\mathrm{BOD}_{5}$ varies according to age of landfills. For new landfills, $\mathrm{BOD}_{5}$ values are $2000-30000 \mathrm{mg} / \mathrm{L}$; for mature landfills, $\mathrm{BOD}_{5}$ varies from $100-200 \mathrm{mg} / \mathrm{L}$ (Tchobanoglous et al., 1993). The values of $\mathrm{BOD}_{5}$ in this study are consistent with those published by other researchers (Aziz et al., 2010; Bashir et al., 2010; Salem et al., 2008). Greater $\mathrm{BOD}_{5}$ values were reported by previous researchers (Aghamohammadi et al., 2007; Aziz et al., 2007; Ntampou et al., 2006; Tatsi \& Zouboulis, 2002). However, the measured $\mathrm{BOD}_{5}$ values for KSLS were greater than the acceptable standard $(50 \mathrm{mg} / \mathrm{L})$. On the contrary, the values for KLS were within the permissible limit.

\subsubsection{COD}

The COD values for leachate at KSLS and KLS varied from $680-950$ and $105-131 \mathrm{mg} / \mathrm{L}$, respectively. According to (Öman \& Junestedt, 2008), leachate in KSLS can be categorized in the methanogenic phase. In this phase, the COD values ranges between 500 and $4500 \mathrm{mg} / \mathrm{L}$. In this study, the obtained COD values were considerably low. Greater COD values were recorded by other studies (Aziz et al., 2010; Aziz et al., 2009; Bashir et al., 2009; Ghafari et al., 2009; Tatsi et al., 2003). Generally, the COD values obtained seemed to have exceeded the permissible limits issued by the Environmental Quality (Control of Pollution from Solid Waste Transfer Station and Landfill) Regulations 2009, Malaysian Environmental Quality Act 1974 (Act 127). For this reason, the landfill leachate required treatment to be environmentally accepted.

\subsection{9 $\mathrm{BOD}_{5} / \mathrm{COD}$ Ratio}

Organics in leachate are characterized by different levels of biodegradability. In this study, the $\mathrm{BOD}_{5} / \mathrm{COD}$ ratios for the collected leachate samples ranged between 0.11-0.26 and between 0.06-0.52 at KSLS and KLS, respectively. The present $\mathrm{BOD}_{5} / \mathrm{COD}$ ratio is consistent with those recorded by other researchers (Aziz et al., 2010; Salem,et al., 2008; Aziz et al., 2007). However, a lower value of 0.043 was obtained by another researcher (Bashir et al., 2009). Generally, the $\mathrm{BOD}_{5} / \mathrm{COD}$ ratio describes the degree of biodegradation and gives information on the age of a landfill. The low $\mathrm{BOD}_{5} / \mathrm{COD}$ ratio shows the high concentration of non-biodegradable organic compounds and thus the difficulty to be biologically degraded (Ntampou et al., 2006).

\subsubsection{Ammonia-N}

For ammonia-N, ranges of 410-1185 and 174-280 mg/L were obtained for the leachate collected from KSLS and KLS, respectively. Greater values of 1070-1300, 983-2117 and1189 mg/L were previously recorded by other studies (Ghafari et al., 2010; Palaniandy et al., 2010; Aziz et al., 2009). The high content of ammonia nitrogen is the main factor that enhances algal growth, promotes eutrophication, disrupts biological treatment operations, and reduces dissolved oxygen (Aziz et al., 2010). As a result, ammonia nitrogen is extremely toxic to the aquatic organisms (Bashir et al., 2010). Typical ammonia-N values of 10-800 and 20-40 mg/L were explained for new (less than two years) and mature (greater than 10 years) landfills, respectively. 


\subsubsection{Sulphate}

Sulphate in leachate collected from KSLS and KLS ranged from 837.60-3025.21 and from 65.83-217.59 mg/L, respectively. Lower sulphate values of $98-374$ and $22-650 \mathrm{mg} / \mathrm{L}$ were previously recorded by other researchers (Kulikowska \& Klimiuk, 2008; Öman \& Junestedt, 2008). Similar ranges of 3056 and 400-2500 mg/L were published other researchers (Ntampou et al., 2006; Tatsi \& Zouboulis, 2002). Typical sulphate values of 300 and $20-50 \mathrm{mg} / \mathrm{L}$ were recorded for new (less than two years) and mature (more than 10 years) landfills, respectively (Tchobanoglous et al., 1993). However, the measured sulphate values were exceeded the permissible level $(0.50$ $\mathrm{mg} / \mathrm{L})$.

\subsubsection{Chloride}

The chloride values for leachate from KSLS and KLS varied from 83.18-1484.33 and 194-292.35 mg/L, respectively. Higher ranges of 490-1190, 360-4900 and 580-10100 mg/L were previously recorded by other researchers (Kulikowska \& Klimiuk, 2008; Öman \& Junestedt, 2008; Tatsi \& Zouboulis, 2002). For new and mature landfills, the chloride values are 500 and $100-400 \mathrm{mg} / \mathrm{L}$, respectively (Tchobanoglous et al., 1993). Leachate samples at KSLS and KLS were found to contain relatively high chloride concentrations. The presence of chloride in landfill leachate at concentrations can be acutely toxic to fresh water organisms and may have been stable over at least two decades (Öman \& Junestedt, 2008).

\subsubsection{Iron $(\mathrm{Fe})$}

The iron values varied at 0.96-3.65 and 0.24-0.71 for KSLS and KLS, respectively. Similar range of 0.32-7.5 mg/L was previously reported (Aziz et al., 2007), confirming the results obtained in this study. However, greater values were previously recorded by numerous authors (Aziz et al., 2010; Bashir et al., 2010; Kulikowska \& Klimiuk, 2008; Öman \& Junestedt, 2008; Aghamohammadi et al., 2007; Aziz et al., 2004). Iron concentration in landfill leachate in both sites was lower than the acceptable limit $(5 \mathrm{mg} / \mathrm{L})$. Heavy metals (such as iron) appear in landfill leachate due to the iron-base material waste from construction materials, paints, pigment colour compounds, polishing agents, and electrical appliances (Aziz et al., 2004).

\subsubsection{Zinc}

The average values of zinc for leachate collected from KSLS and KLS were 0.14-0.34 and 0.01-0.29 mg/L, respectively. Greater values ( 2.06 and $1.43 \mathrm{mg} / \mathrm{L}$ ) were recorded in other studies (Aghamohammadi et al., 2007; Ntampou et al., 2006). The results obtained in this study were within the permissible limit ( $1 \mathrm{mg} / \mathrm{L})$. As the landfill ages, the increase in $\mathrm{pH}$ values causes a decrease in metal solubility. This affects the oxidation-reduction process and dissociation of acid. The heavy metals react with the hydrogen ion and precipitate in metal hydroxides. At this stage, the stabilized leachate contains less concentration of heavy metal (less than $2 \mathrm{mg} / \mathrm{L}$ ) due to the high $\mathrm{pH}$ value (Kulikowska \& Klimiuk, 2008).

\subsubsection{Other Heavy Metals ( $\mathrm{Cu}, \mathrm{Ni}$ and $\mathrm{Mn})$}

The average values of $\mathrm{Cu}, \mathrm{Ni}$, and $\mathrm{Mn}$ in the leachate from KSLS and KLS were found to be relatively low (less than $1 \mathrm{mg} / \mathrm{L}$ ). Results of this study are consistent with those of previous authors (Ntampou et al., 2006; Tatsi \& Zouboulis, 2002). The measured results were below the allowed limit $(0.20 \mathrm{mg} / \mathrm{L})$ set in the Environmental Quality (Control of Pollution from Solid Waste Transfer Station and Landfill) Regulations 2009, Malaysian Environmental Quality Act 1974 (Act 127).

\subsection{Variations in Leachate Compositions and Treatment Strategy}

Landfill leachate contains large amounts of pollutants measured as COD, $\mathrm{BOD}_{5}$, ammonia-N, SS, heavy metals, phenols, and phosphorus (Aziz et al., 2010; Foul et al., 2009; Renou et al., 2008). In general, the pollutants in landfill leachate could be categorized as: 1) organic constituents, including volatile fatty acids, humic, and fulvic substances; 2) inorganic constituents, such as chloride, sulphate, ammonia-N, phosphate, and sodium; and 3) heavy metals, such as plumbum, nickel, manganese, iron, zinc, etc. Three main groups of landfills are classified as young (less than five years), intermediate (5-10 years), and old or stabilized (more than 10 years). Table 2 summarizes the typical characteristics of leachate according to age of landfill. 
Table 2. Characteristics of leachate at different ages of landfill (Renou et al., 2008; Amokrane et al., 1997)

\begin{tabular}{llll}
\hline \multirow{2}{*}{ Constituent } & \multicolumn{3}{c}{ Landfill age and leachate type } \\
\cline { 2 - 4 } & Young $(<5$ years $)$ & Intermediate $(5-10$ years $)$ & Stabilized ( $>10$ years $)$ \\
\hline $\mathrm{pH}$ & $<6.5$ & $6.5-7.5$ & $>7.5$ \\
$\mathrm{COD}(\mathrm{mg} / \mathrm{L})$ & $>10000$ & $4000-10000$ & $<4000$ \\
$\mathrm{BOD}_{5} / \mathrm{COD}$ & $>0.3$ & $0.1-0.3$ & $<0.1$ \\
Organics compounds & $80 \%$ volatile fatty acids $(\mathrm{VFA})$ & $5-30 \%$ VFA+humic and fulvic acids & Humic and fulvic acids \\
Heavy metals & Low to medium & Low & Low \\
Biodegradability & Important & Medium & Low \\
\hline
\end{tabular}

The leachate produced in young landfills contains substantial amounts of volatile acids resulting from the acid phase of fermentation. In stabilized landfills, the great portion of organics in leachate are fulvic and humic substances. Results of this study indicate large variation in concentration of leachate parameters at both sites. This is due to the effect of local climate conditions on the leachate compositions.KSLS and KLS are under humid condition with a high intensity of rainfall. The variation of leachate characteristics is attributed to a number of reasons, including composition of the solid waste, precipitation rates, interaction of leachate with the environment, and landfill design and operation. This study shows that pollutant concentrations in KSLS were slightly higher than those in KLS. The low difference between KSLS and KLS is due to the age of both landfills (more than 14 years). The results showed that KSLS generated dark brown liquid, which could be considered stable (methanogenic conditions) with high concentrations of COD and ammonia-N and low $\mathrm{BOD}_{5} / \mathrm{COD}$ ratio. The high concentration of COD in KSLS indicated that the leachate contained low concentration of volatile fatty acids and large amount of fulvic and humic substances. A decrease in $\mathrm{BOD}_{5}$ and $\mathrm{COD}$ is often reported with an increase in age of a landfill. Ammonia can have a negative impact on the environment. The stabilized landfill leachates (methanogenic phase) usually are highly contaminated with ammonia resulting from the hydrolysis and fermentation of nitrogen containing fractions of biodegradable refuse substrate. This pollutant is extremely toxic to the aquatic organisms (Bashir, et.al., 2010). Generally, the potential methods for leachate treatment are biological, physico-chemical, and the combination of biological and physico-chemical treatment processes. However, the physico-chemical treatment process has been found to be very effective in reducing pollutants from the stabilized leachate. Based on the characterization of landfill leachate at KSLS and KLS, an integrated technology should be developed, and a physico-chemical treatment must be applied before effluent is discharged.

\section{Conclusions}

Leachate characteristics of two landfill sites were examined. The data presented in this study indicate that the age of the leachate has a significant effect on its composition. Obviously, as a landfill ages, the biodegradable fraction of organic pollutants in the leachate decreases as an outcome of the anaerobic decomposition occuring in the landfill. Generally, the concentration of leachate contaminants at KSLS were greater than that at KLS. Based on the characterization of landfill leachate, KSLS demonstrated low biodegradability $\left(\mathrm{BOD}_{5} / \mathrm{COD}=0.19\right)$ compared with $\mathrm{KLS}\left(\mathrm{BOD}_{5} / \mathrm{COD}=0.24\right)$. A wide range of measured parameters in both sites, such as colour, seemed to be affected by the rainfall, which caused dilution of the generated landfill leachate at the collection pond. As a result, the implementation of the most suitable technology for the treatment of landfill leachate should be considered after fully understanding the composition and concentration of leachate.

\section{Acknowledgement}

Thanks to Majlis Perbandaran Taiping, Perak and Majlis Perbandaran Kulim, Kedah for providing access to the landfill for the collection of leachates.

\section{References}

Aghamohammadi, N., Aziz, H. A., Isa, M. H., \& Zinatizadeh, A. A. (2007). Powdered activated carbon augmented activated sludge process for treatment of semi-aerobic landfill leachate using response surface methodology. Bioresource Technology, 98, 3570-3578. http://dx.doi.org/10.1016/j.biortech.2006.11.037

Amokrane, A., Comel, C., \& Veron, J. (1997). Landfill leachates pretreatment by coagulation-flocculation. Water Research, 31, 2775-2782. http://dx.doi.org/10.1016/S0043-1354(97)00147-4 
APHA. (2005). Standard methods for the examination of water and wastewater (21st ed.). Washington, DC: American Public Health Association.

Aziz, H. A., Alias, S., Adlan, M. N., Asaari, F. A. H., \& Zahari, M. S. M. (2007) Colour removal from landfill leachate by coagulation and flocculation process. Bioresource Technology, 98, 218-220. http://dx.doi.org/10.1016/j.biortech.2005.11.013

Aziz, H. A., Daud, Z., Adlan, M. N., \& Hung, Y. T. (2009). The use of polyaluminium chloride for removing colour, COD and ammonia from semi-aerobic leachate. International Journal of Environmental Engineering, 1, 20-35. http://dx.doi.org/10.1504/IJEE.2009.026440

Aziz, H. A., Yusoff, M. S., Adlan, M. N., Adnan, N. H., \& Alias S. (2004). Physico-chemical removal of iron from semi-aerobic landfill leachate by limestone filter. Waste Management, 24, 353-358. http://dx.doi.org/10.1016/j.wasman.2003.10.006

Aziz, S. Q., Aziz, H. A., Yusoff, M. S., \& Bashir, M. J. K. (2010). Leachate characterization in semi-aerobic and anaerobic sanitary landfills: A comparative study. Journal of Environmental Management, 91, 2608-2614. http://dx.doi.org/10.1016/j.jenvman.2010.07.042

Bashir, M. J. K., Aziz, H. A., Yusoff, M. S., \& Adlan, M. N. (2010). Application of response surface methodology (RSM) for optimization of ammonical nitrogen removal from semi-aerobic landfill leachate using ion exchange resin. Desalination, 254, 154-161. http://dx.doi.org/10.1016/j.desal.2009.12.002

Foul, A. A., Aziz, H. A., Johari, M. A. M., Ariffin, K. S., \& Hung, Y. T. (2009). Primary treatment of anaerobic landfill leachate using activated carbon and limestone: Batch and column studies. International Journal of Environment and Waste Management, 4, 282-298. http://dx.doi.org/10.1504/IJEWM.2009.027397

Ghafari, S., Aziz, H. A., \& Bashir, M. J. K. (2010). The use of poly-aluminum chloride and alum for the treatment of partially stabilized leachate: A comparative study. Desalination, 257, 110-116. http://dx.doi.org/10.1016/j.desal.2010.02.037

Jokela, J. P. Y., Kettunen, R. H., Sormunen, K. M., \& Rintala, J. A. (2002). Biological nitrogen removal from municipal landfill leachate: low-cost nitrification in biofilters and laboratory lab scale in-situ denitrification. Water Research, 36, 4079-4087. http://dx.doi.org/10.1016/S0043-1354(02)00129-X

Kang, K. H., Shin, H. S., \& Park, H. (2002). Characterization of humic substances present in landfill leachates with different landfill ages and its implications. Water Research, 36, 4023-4033. http://dx.doi.org/10.1016/S0043-1354(02)00114-8

Kulikowska, D., \& Klimiuk, E. (2008). The effect of landfill age on municipal leachate composition. Bioresource Technology, 99, 5981-5985. http://dx.doi.org/10.1016/j.biortech.2007.10.015

Manaf, L. A., Samah, M. A. A., \& Zukki, N. I. M. (2009). Municipal solid waste management in Malaysia: $\begin{array}{llll}\text { Practices and } & \text { 2902-2906. }\end{array}$ http://dx.doi.org/10.1016/j.wasman.2008.07.015

MDC. (2010). Laws of Malaysia-Environmental Quality Act 1974 and Regulations. Kuala Lumpur, Malaysia: MDC.

Mohajeri, S., Aziz H. A., Isa M. H., Zahed M. A., \& Adlan M. N. (2010). Statistical optimization of process parameters for landfill leachate treatment using electro-fenton technique. Journal of Hazardous Materials, 176, 749-758. http://dx.doi.org/10.1016/j.jhazmat.2009.11.099

Ntampou, X., Zouboulis, A. I., \& Samaras, P. (2006). Appropriate combination of physicochemical methods (coagulation/flocculation and ozonation) for the efficient treatment of landfill leachates. Chemosphere, 62, 722-730. http://dx.doi.org/10.1016/j.chemosphere.2005.04.067

Öman, C. B., \& Junestedt, C. (2008). Chemical characterization of landfill leachates-400 parameters and compounds. Waste Management, 28, 1876-1891. http://dx.doi.org/10.1016/j.wasman.2007.06.018

Palaniandy, P., Adlan, M. N., \& Aziz, H.A., Murshed M.F. (2010). Application of dissolved air flotation (DAF) in semi-aerobic leachate treatment. Chemical Engineering Journal, 157, 316-322. http://dx.doi.org/10.1016/j.cej.2009.11.005

Poznyak, T. G., Bautista, L., Chairez, I. R., Cordova, I., \& Rios, E. (2003). Decomposition of toxic pollutants in landfill leachate by ozone after coagulation treatment. Journal of Hazardous Materials, 152, 1108-1114. 
Renou, S., Givaudan, J. G., Poulain, S., Dirassouyan, F., \& Moulin, P. (2008). Landfill leachate treatment: Review and opportunity. Journal of Hazardous Materials, 150, 468-493. http://dx.doi.org/10.1016/j.jhazmat.2007.09.077

Rivas, F. J., Beltran, F. B., Carvalho, F., Acedo, B., \& Gimeno, O. (2004). Stabilized leachate: Sequential coagulation-flocculation+chemical oxidation process. Journal of Hazardous Materials, B116, 95-102. http://dx.doi.org/10.1016/j.jhazmat.2004.07.022

Salem, Z., Hamouri, K., Djemaa, R., \& Allia, K. (2008). Evaluation of landfill leachate pollution and treatment. Desalination, 220, 108-114. http://dx.doi.org/10.1016/j.desal.2007.01.026

Sanphoti, N., Towprayoon, S., Chaiprasert, P., \& Nopharatana, A. (2006). The effects of leachate recirculation with supplemental water addition on methane production and waste decomposition in a simulated tropical $\begin{array}{llllll}\text { landfill. Journal of } & \text { Environmental }\end{array}$ http://dx.doi.org/10.1016/j.jenvman.2005.10.015

Tatsi, A. A., \& Zouboulis, A. I. (2002). A field investigation of the quantity and quality of leachate from municipal solid waste in mediterranean climate. Advances in Environmental Research, 6, 207-219. http://dx.doi.org/10.1016/S1093-0191(01)00052-1

Tatsi, A. A., Zouboulis, A. I., Matis, K. A., \& Samaras, P. (2003). Coagulation-flocculation pretreatment of sanitary landfill leachates. Chemosphere, 53, 737-747. http://dx.doi.org/10.1016/S0045-6535(03)00513-7

Tchobanoglous, G., Theisen, H., \& Vigil, S. A. (1993). Integrated solid waste management engineering principles and management issues (1st ed.). New York, NY: McGraw-Hill.

Wang, Z. P., Zhang, Z., Lin Y. J., Deng, N. S., Tao, T., \& Zhuo, K. (2002). Landfill leachate treatment by a coagulation-photooxidation process. Journal of Hazardous Materials, 95, 153-159. http://dx.doi.org/10.1016/S0304-3894(02)00116-4

Zhong, Q., Li, D., Tao, Y., Wang, X., He, X., Zhang, J., ... Wang, L. (2009). Nitrogen removal of landfill leachate via ex situ nitrification and sequential in situ denitrification. Waste Management, 29, 1347-1353. http://dx.doi.org/10.1016/j.wasman.2008.10.014 